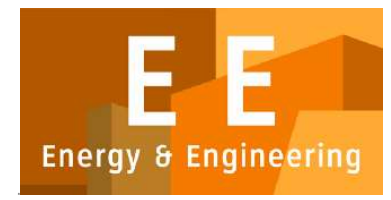

PAPER - OPEN ACCESS

\title{
Perencanaan Tata Guna Lahan Dalam Mendukung Pengembangan Desa Wisata Tongging yang Berkelanjutan
}

\author{
Author $\quad$ : Nurlisa Ginting dan Habibi Lubis \\ DOI $\quad: 10.32734 /$ ee.v3i1.864 \\ Electronic ISSN $\quad: 2654-704 \mathrm{X}$ \\ Print ISSN : :2654-7031
}

Volume 3 Issue 1 - 2020 TALENTA Conference Series: Energy \& Engineering (EE)

This work is licensed under a Creative Commons Attribution-NoDerivatives 4.0 International License.

Published under licence by TALENTA Publisher, Universitas Sumatera Utara 


\title{
jibiti (4) TALENTA Conference Series
}

Available online at https://talentaconfseries.usu.ac.id/ee

\section{Perencanaan Tata Guna Lahan Dalam Mendukung Pengembangan Desa Wisata Tongging yang Berkelanjutan}

\section{Land Use Planning in Supporting the Development of a Sustainable Tongging Tourism Village}

\author{
Nurlisa Gintinga,b,c, Habibi Lubis ${ }^{\text {a* }}$ \\ ${ }^{a}$ Program Studi Magister Teknik Arsitektur, Fakultas Teknik, Universitas Sumatera Utara, Jalan Perpustakaan Gedung J7 Kampus USU, Medan, 20155, Indonesia \\ ${ }^{b}$ Kelompok Kerja Pariwisata Kawasan Danau Toba dan Pariwisata Berkelnajutan, Universitas Sumatera Utara, Jalan Dr. Mansyur Kampus USU, Medan, 20155, \\ Indonesia \\ ${ }^{c}$ Monitoring Centre for Sustainable Tourism Observatory (MCSTO) Universitas Sumatera Utara, Jalan Perpustakaan Gedung J7 Kampus USU, Medan, 20155,
} Indonesia

nurlisa@usu.ac.id,mr_loebis@yahoo.com

\begin{abstract}
Abstrak
Desa Tongging merupakan bagian dari Kawasan Strategis Nasional (KSN) Danau Toba yang berada di Kabupaten Karo dan juga menjadi bagian dari Kawasan Geopark Kaldera Toba. Sebagai daerah tujuan wisata, Desa Tongging belum memiliki konsep tata guna lahan yang dapat memaksimalkan potensi kawasan sebagai tujuan wisata. Pemanfaatan area sempadan danau sebagai respon masyarakat terhadap kebutuhan wisatawan justru bertentangan dengan prinsip tata guna lahan yang diamanatkan dalam Rencana Tata Ruang KSN Danau Toba. Tata guna lahan yang baik seharusnya dapat meningkatkan nilai dan keberlajutan sebuah kawasan. Oleh karena itu penelitian ini bertujuan membuat konsep perencanaan tata guna lahan tongging yang berkelanjutan sebagai desa wisata. Penelitian dilakukan dengan metoda kualitatif dengan memafaatkan data hasil observasi lapangan dan studi literatur. Analisa studi menggunakan tiga elemen yaitu pengaturan zonasi, pembagian fungsi, dan peningkatan nilai kawasan. Penelitian menghasilkan perencanaan tata guna lahan tongging sebaga desa wisata yang berkelanjutan.
\end{abstract}

Kata kunci: Tata Guna Lahan, Desa Wisata, Berkelanjutan, Tongging ;

\section{Abstract}

Tongging Village is part of the Lake Toba National Strategic Area (KSN) in Karo District and also part of the Toba Caldera Geopark Area. As a tourist destination, Tongging Village does not yet have a land use concept that can maximize the potential of the region as a tourist destination. Utilization of the lake border area as a public response to the needs of tourists is contrary to the land use principle mandated in the Lake Toba KSN Spatial Plan. Good land use should increase the value and sustainability of an area. Therefore this study aims to make the concept of planning a sustainable land use tongging as a tourist village. The study was conducted using qualitative methods by using data from field observations and literature studies. Analysis of the study uses three elements, namely zoning arrangements, division of functions, and increasing the value of the area. The research resulted in the planning of land use tongging as a sustainable tourist village.

Keywords: Land Use, Tourism Village, Sustainable, Tongging;

\section{Pendahuluan}

Desa Tongging terletak di kawasan Merek, Kabupaten Karo yang berjarak sekitar 40 km dari kota Brastagi. Tongging sudah lama menjadi daerah tujuan wisata di Sumatera utara khususnya danau toba. Tongging memiliki alam yang indah dengan view pemandangan ke arah danau toba. Tongging juga terkenal dengan pertaniannya. Ada banyak sawah, ladang bawang, mangga, dan juga peternakan ikan. Data kunjungan wisatawan yang berkunjung ke Desa Tongging tercatat mencapai seratus ribu wisatawan setiap tahunnya, namun para wisatawan yang berkunjung pada umumnya adalah wisatawan harian untuk sekedar menikmati pemandangan danau toba dan kuliner ikan bakar kemudian kembali ke Brastagi [2].

Desa Tongging memiliki banyak objek wisata untuk dikunjungi seperti objek wisata Air Terjun Sipiso-piso, Taman Simalem, Bukit Gajah Bobok, dan Taman Bunga Sopo Juma. Potensi perkampungan pada area tepi air yang menjadi titik konsentrasi aktivitas masyarakat seperti kegiatan pertanian, kebun, dan ternak ikan juga tidak kalah menarik untuk dikembangkan menjadi tujuan wisata. Namun sejauh ini belum terlihat ada konsep pengembangan yang mengakomodasi aktivitas masyarakat desa tongging menjadi bagian dari pariwisata. Ketiadaan konsep pengembangan ini membuat potensi yang ada belum terekspose bagi pengunjung sebagai bagian 
dari pariwisata. Aktivitas masyarakat seperti pemanfaatan sempadan danau berupa restoran ikan sebagai respon masyarakat terhadap kebutuhan wisatawan justru bertentangan dengan prinsip tata guna lahan kawasan danau toba yang mengamanatkan area sempadan danau sebagai area fungsi hijau [3].

Kawasan desa tongging khususnya pada area perkampungan yang menjadi titik konsentrasi aktivitas masyarakat belum memiliki konsep perencanaan terhadap tata guna lahan terkait dengan pelestarian kawasan sempadan danau dan pembagian fungsi kawasan sebagai kawasan pariwisata. Untuk memenuhi hal tersebut penelitian ini dilakukan untuk merumuskan sebuah konsep perencanaan tata guna lahan yang paling sesuai dengan kondisi eksisting desa tongging. Konsep yang diajukan adalah konsep pariwisata berkelanjutan sebagai desa wisata. Konsep ini diajukan karena dianggap sebagai konsep yang mampu mensejahterakan kehidupan masyarakat lokal namun tetap memperhatikan kelestarian kawasan.

\section{Tinjauan Pustaka}

\subsection{Desa Wisata Berkelanjutan}

Desa Wisata (rural tourism) merupakan pariwisata yang terdiri dari keseluruhan pengalaman pedesaan, atraksi alam, tradisi, unsur - unsur yang unik yang secara keseluruhan dapat menarik minat wisatawan [4]. Pariwisata perdesaan disebutkan Lane [5] harus memperhatikan hal-hal seperti : (1) Lokasi harus di daerah perdesaan, (2) Fungsi perdesaan dikembangkan dalam suasana perdesaan yang memiliki ciri khusus, yaitu usaha kecil, ruang terbuka, berhubungan dengan alam dan keaslian kegiatan masyarakat tradisional, (3) Bersifat tradisional, berkembang secara perlahan dan berhubungan dengan masyarakat lokal, (4) Skala perdesaan baik bentuk bangunan maupun pengaturan harus selalu dalam skala kecil, (5) Menyajikan bentuk yang komplek dari lingkungan perdesaan, ekonomi, sejarah, dan lokasinya. Sesuai dengan defenisi yang telah dikemukakan oleh beberapa ahli tentang desa wisata maka desa tongging sangat layak untuk dikembangkan sebagai desa wisata.

Pariwisata sangat erat kaitannya dengan ekonomi, pengembangan pariwisata umumnya dikembangkan untuk meningkatkan ekonomi masyarakat pada kawasan dimana pariwisata itu dikembangkan. Disamping tujuan ekonomi, pelestarian nilai budaya dan alam menjadi hal penting untuk mencegah kerusakan nilai budaya dan alam sekitar dimasa yang akan datang. Konsep pengembangan pariwisata yang bertujuan mensejahterakan kehidupan masyarakat lokal namun tetap memperhatikan kelestarian budaya dan alam ini dikenal dengan istilah pariwisata berkelanjutan (sustainable tourism) [6]. Salah satu bentuk pariwisata berkelanjutan itu adalah konsep desa wisata. Desa wisata merupakan konsep pariwisata yang terbukti berpihak pada masyarakat lokal [7]. Banyak desa yang dikembangkan sebagai desa wisata di indonesia disebutkan telah berhasil meningkatkan taraf hidup masyarakat lokal. Kementerian pariwisata telah menetapkan bahwa program pengembangan desa wisata menjadi agenda prioritas dalam pengembangan pariwisata indonesia. Kementerian pariwisata memberikan penghargaan bagi desa-desa yang berhasil dalam pengembangan desa wisata melalui program ISTA (Indonesia Sustainable Tourism Award).

Dalam perencanaan dan perancangan guna lahan kawasan desa wisata pada prinsipnya sama dengan perencanaan dan perancangan kota pada umumnya namun dalam perancangan desa wisata perlu menghadirkan nilai lokalitas kawasan seperti aspek sosial budaya masyarakatnya dalam desain kawasan sebagai usaha dalam menunjukkan identitas masyarakat setempat sebagai bagian dari objek yang dapat ninikmati oleh wisatawan [6]. Pembagian zona pada desa wisata dibagi menjadi empat yaitu (1) zona konservasi rumah penduduk sebagai zona yang melindungi rumah penduduk sebagai aset kebudayaan desa wisata dan sebagai basis pengembangan home industry; (2) zona pengembangan sebagai zona yang diperuntukkan untuk pusat kegiatan desa wisata seperti atraksi wisata dan sebagainya yang memiliki atau mempunyai potensi sebagai point of view dan sebagai pintu utama untuk masuk ke desa wisata; (3) zona komersial sebagai yang zona yang diperuntukkan untuk pengembangan usaha penyediaan akomodasi homestay untuk tempat tinggal wisatawan yang ingin menginap di desa wisata; (4) zona transisi adalah zona yang diperuntukkan sebagai lahan terbuka untuk mengembangkan atraksi wisata buatan seperti agro wisata dan pengembangan teknologi ramah lingkungan seperti pembangkit listrik tenaga matahari/surya, biogas dan lain-lain [6].

Kajian studi sejenis terhadap penataan guna lahan pada desa wisata yang dilakukan penulis pada tiga desa wisata memperlihatkan pola yang telah dijelaskan oleh Antara, misalnya adalah Desa Sade, Nusa tenggara barat, membagi kawasan desa kepada beberapa zona antara lain zona permukiman tradisional sebagai zona yang melestarikan rumah adat suku sasak sebagai warisan budaya yang terus dipertahankan dan tidak boleh dirubah. Jika masyarakat ingin membangun maka diperbolehkan pada zona permukiman baru yang berada disekeliling zona perkampungan tradisional. Zona komersial dipusatkan di area pinggir jalan utama sebelum memasuki area dusun sade tradisional yang menjadi objek wisata utama. Pada sisi terluar perkampungan merupakan areal persawahan dan perkebunan yang dapat dinikmati view dari dalam kawasan permukiman. Desa kedua adalah Desa Penting Sari, Yogyakarta, membagi zona desa untuk beberapa aktivitas wisata seperti camping ground, pertanian dan perkebunan, dan area permukiman masyarakat dijadikan homstay bagi pengunjung. Desa ketiga adalah Desa Kutuh, Bali, membagi zona desa pada beberapa zona seperti permukiman, komersial, dan zona pelestarian alam dan cagar budaya. Area tempat-tempat suci seperti pura dan area suci lainnya dilarang dibangun untuk penggunaan lain. Pada zona ini sering dilakukan upacara adat lokal yang menjadi objek wisata bagi wisatawan. 
Ginting [1] melakukan analisa terhadap konsep tata guna lahan untuk pariwisata berkelanjutan berdasarkan tiga elemen antara lain (1) pembatasan zona, (2) pembagian fungsi, dan (3) peningkatan nilai kawasan. Pembatasan zona dilakukan untuk membatasi kawasan yang perlu dikonservasi dengan kawasan yang menjadi pengembangan kegiatan pariwisata agar tidak terjadi konflik kepentingan antara aspek konservasi dengan aspek pariwisata. Pembagian fungsi didasarkan pada potensi eksisting kawasan berupa aktivitas masyarakat yang sudah ada juga kondisi alam yang menjadi objek menarik bagi wisatawan. Peningkatan nilai kawasan dilakukan sebagai upaya mengembangkan lahan-lahan yang sebelumnya belum memiliki nilai, namun dengan adanya pengaturan konsep tata guna lahan maka nilai kawasan lahan tersebut menjadi meningkat.

\section{Metode Penelitian}

Daerah yang menjadi kawasan penelitian adalah Desa Tongging, Kecamatan Merek, Kabupaten Karo. Penelitian ini dibatasi pada wilayah yang menjadi konsentrasi permukiman yang berada di tepi air danau toba (Gambar 1).

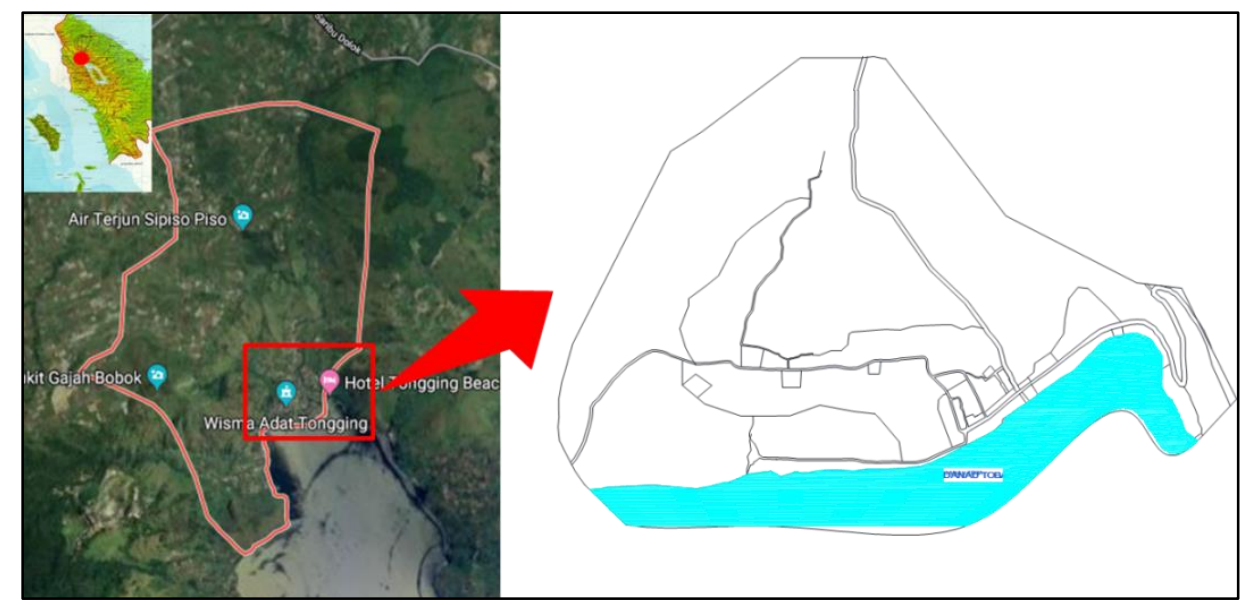

Gambar 1. Kawasan Perencanaan

Penelitian ini adalah penelitian kualitatif yaitu didasari pada studi literatur tentang konsep guna lahan pada desa wisata dan melakukan studi banding terhadap proyek sejenis yaitu Desa Sade di Nusa Tenggara Barat, Desa Penting Sari di Jogjakarta, Desa Kutuh di Bali. Hasil studi literatur dan studi banding sejenis dipadukan dengan kondisi eksisting kawasan. Dasar penentuan konsep tata guna lahan dilakukan dengan melihat potensi wisata serta permasalahan dan kendala yang ada sehingga ditemukan konsep penataan guna lahan yang konteks dengan desa tongging sebagai desa wisata. 


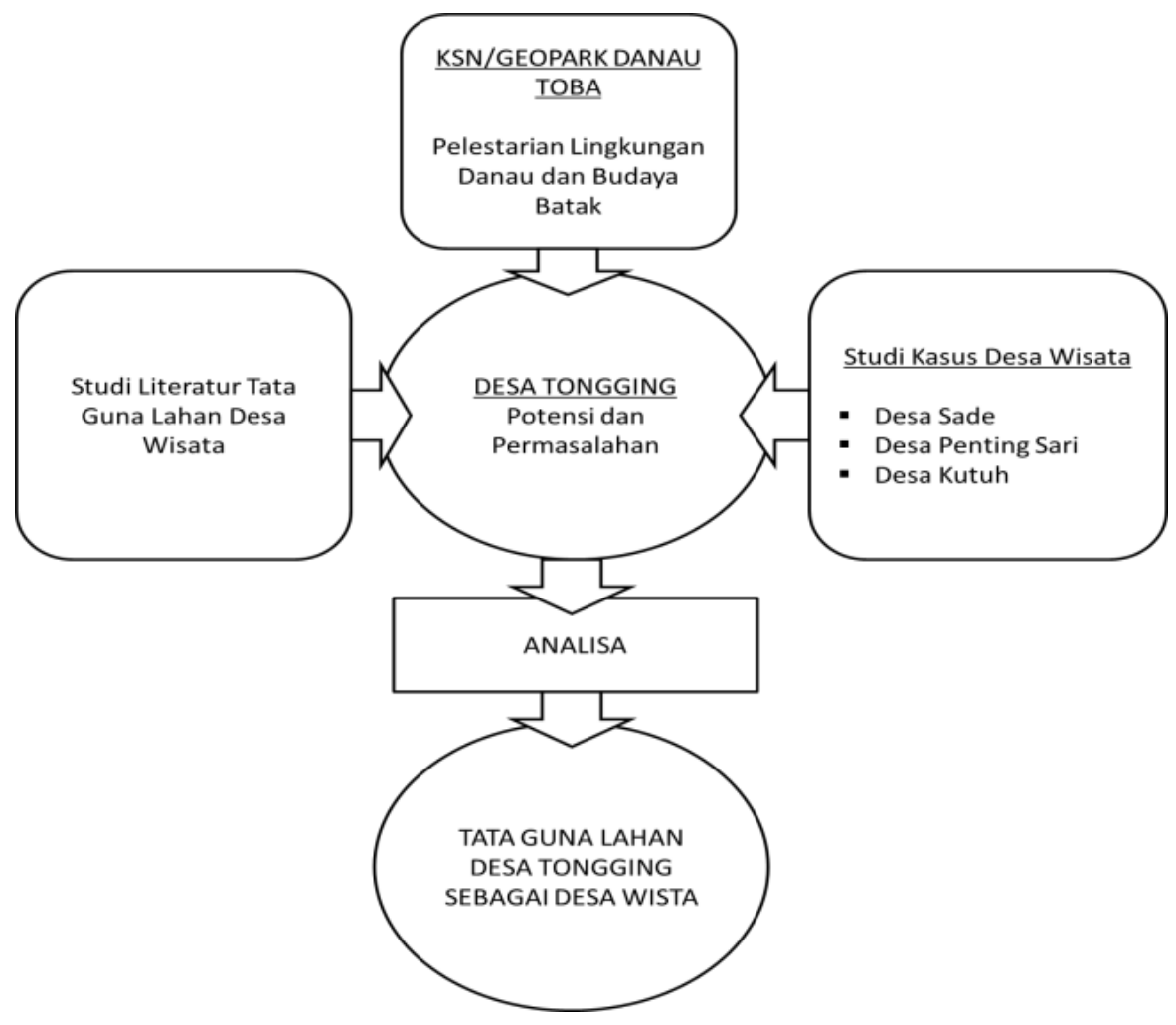

Gambar 2. Metoda Analisa Penelitian

\section{Hasil dan Pembahasan}

Kawasan Desa Tongging sudah lama dikenal sebagai daerah tujuan wisata. Beberapa objek yang menjadi tujuan wisatawan adalah seperti Air Terjun Sipiso-piso, Bukit Gajah Bobok, Taman Bunga Sopo Juma, Taman Simalem, dan Pusat Perkampungan Desa Tongging yang berada di area tepi air danau toba. Sayangnya menurut data Dinas Pariwisata Kabupaten Karo kebanyakan wisatawan yang berkunjung ke desa tongging adalah wisatawan harian. Wisatawan hanya sekedar menikmati suasana alam danau toba dan kemudian kembali ke Brastagi. Dengan keindahan alam dan keunikan kawasannya, desa tongging seharusnya dapat lebih dimaksimalkan sebagai tujuan wisata dengan konsep desa wisata sehingga pengunjung memiliki banyak aktivitas wisata yang dilakukan dan tinggal lebih lama, dengan demikian masyarakat setempat lebih merasakan manfaat pariwisata dan dapat meningkatkan taraf hidup masyarakat. Sebagaimana dijelaskan oleh Joshi [4] desa wisata dapat memadukan antara atraksi alam dengan kehidupan keseharian masyarakat setempat sebagai pengalaman wisata bagi pengunjung.

Sejauh ini belum banyak aktivitas yang dapat dilakukan oleh wisatawan yang berkunjung ke desa tongging. Aktivitas yang umum dilakukan adalah masih sebatas wisata kuliner ikan. Aktivitas itu dapat dilihat dengan banyaknya warung tempat makan ikan disepanjang tepi air danau toba. Area perkampungan desa tongging sebenarnya memiliki banyak potensi wisata yang dapat dikembangkan. Jika melihat guna lahan eksisting desa tongging, kawasan desa tongging terdiri dari tiga kategori guna lahan yaitu lahan permukiman penduduk, lahan komersial seperti rumah toko dan restoran, dan lahan pertanian seperti sawah, bawang, dan kebun mangga.

Area komersial berupa rumah toko dapat dilihat pada sisi kiri dan kanan jalur utama pintu masuk jalan yang melintasi Desa Tongging menuju Silalahi. Area permukiman mengikuti pola jaringan jalan. Lahan-lahan pertanian tersebar di luar area permukiman dengan tidak berpola. Beberapa hotel atau penginapan berada pada area pintu masuk kawasan dan pada area barat setelah melewati perkampungan menuju desa silalahi. Sisanya adalah lahan-lahan kosong yang belum dimanfaatkan. Secara umum penggunaan lahan pada desa tongging diperlihatkan pada gambar 3 sebagai berikut. 


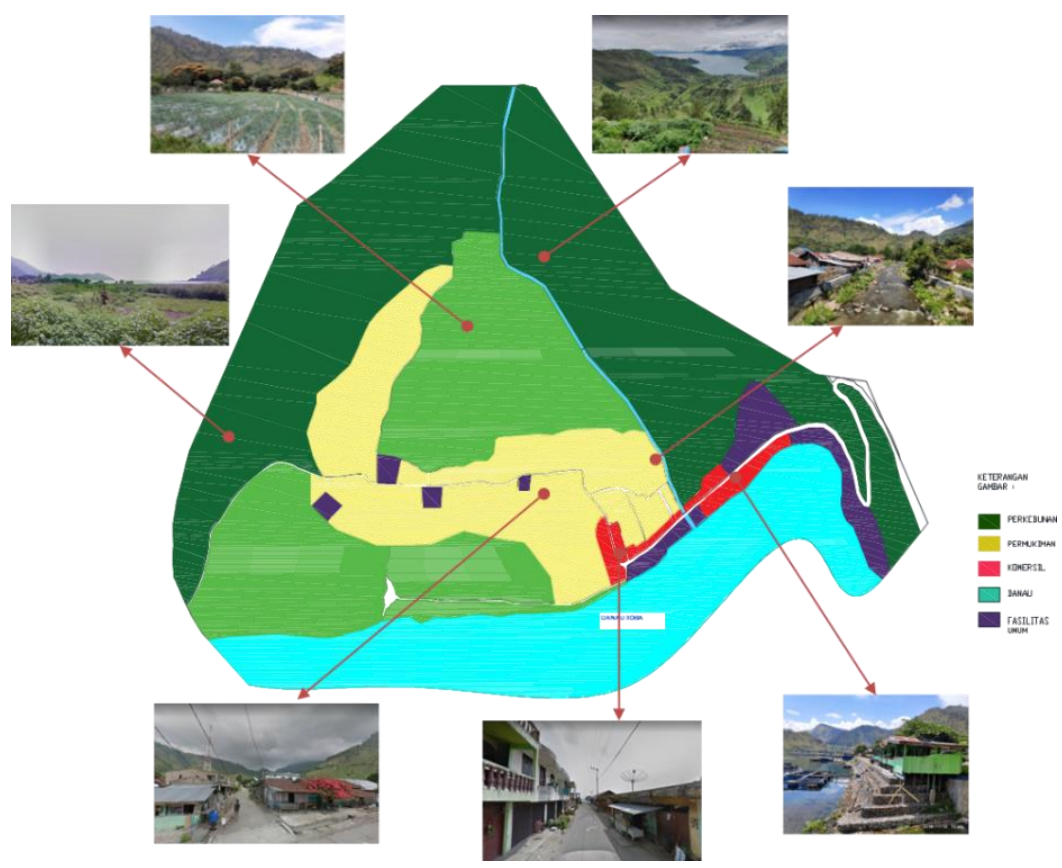

Gambar 3. Gunan Lahan Eksisting Desa Tongging

Secara umum dapat dilihat bahwa belum ada penataan terhadap kawasan desa tongging untuk memaksimalkan kawasan tersebut sebagai daerah tujuan wisata, oleh kareana itu perlu sebuah perencanaan guna lahan desa tongging sebagai desa wisata. Sebagai bagian dari KSN Danau Toba, Desa Tongging juga harus memperhatikan pelestarian kawasan sempadan danau, oleh karena itu mengembalikan kembali fungsi kawasan sempadan sebagai jalur hijau adalah hal yang wajib dilakukan.

\subsection{Pembatasan Zonasi Guna Lahan}

Pembatasan zonasi guna lahan tongging dilakukan sebagai upaya untuk melestarikan zona sempadan danau yang menjadi kawasan dengan fungsi hijau. Kawasan sempadan danau diamanatkan dalam peraturan presiden tentang KSN Danau Toba sepanjang 50 meter dari tepi air menjadi kawasan yang berfungsi kawasan hijau. Aktivitas masyarakat desa tongging berupa restoran ikan pada area yang menjadi sempadan ini tidak tepat sehingga perlu dilakukan pembatasan dengan mengembalikan zona sempadan sebagai fungsi hijau dengan menjadikan kawasan tersebut sebagai ruang terbuka berupa taman yang dapat dinikmati wisatawan (gambar 4)

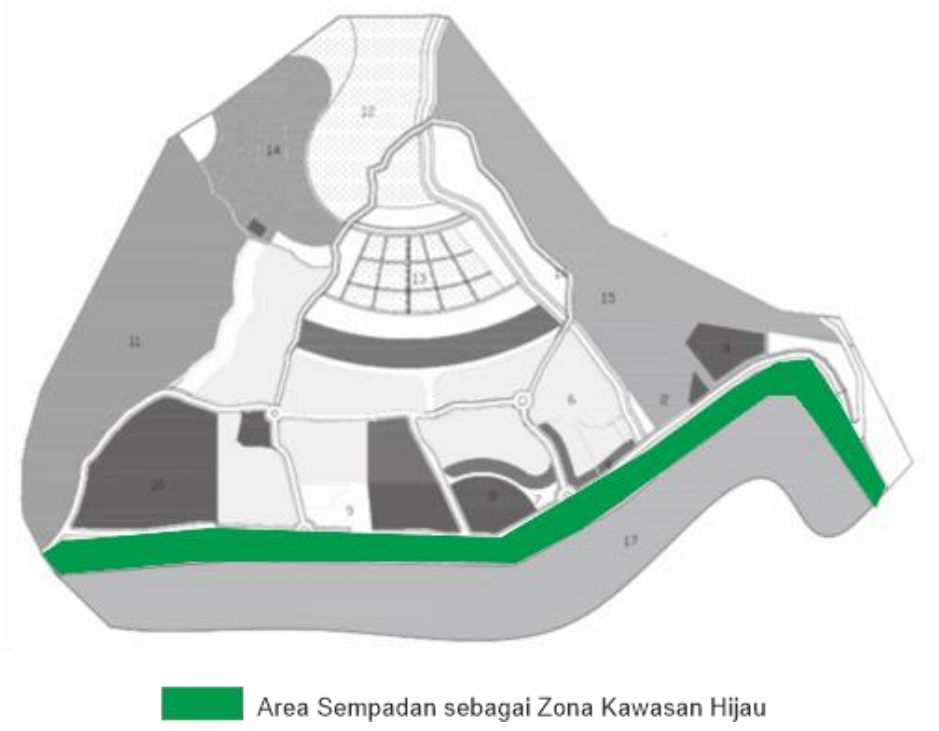

Gambar 4. Sempadan Sebagai Zona Hijau Membatasi Kawasan Dengan Danau Toba 


\subsection{Pembagian Fungsi}

Belajar dari desa wisata sade, kawasan permukiman tradisional sade dipertahankan sebagai kawasan objek wisata. Kawasan perumahan tradisional menawarkan homstay rumah tradisional sasak beserta kehidupan sosial dan budayanya. Pengembangan permukiman dilakukan pada area di sekeliling perumahan tradisional tanpa mengganggu kawasan perumahan tradisional yang ada. Kawasan desa wisata tongging memiliki potensi untuk pengembangan rumah tradisional karo yang dapat dijadikan sebagai homstay bagi pengunjung. Kawasan rumah tradisional dapat dibangun pada area yang belum berkembang. Pengembangan area perumahan tradisional ini juga sebagai solusi untuk mengurangi kemungkinan semakin padatnya kawasan permukiman yang ada sekarang di masa yang akan datang.

Pada desa wisata penting sari rumah masyarakat juga dijadikan sebagai homstay. Selain homstay disediakan juga area khusus untuk aktivitas wisata alam seperti wisata bajak sawah dan menanam padi, wisata outbond, dan wisata kesenian gamelan. Konsep seperti ini yang dijelaskan oleh Joshi [4] sebagai kosep desa wisata yang menawarkan unsur alam dan budaya keseharian masyarakat menjadi satu kesatuan wisata yang dapat dinikmati oleh wisatawan. Desa tongging sangat potensial untuk megadopsi beberapa hal pada studi rujukan untuk diaplikasikan seperti membuat zona khusus untuk wisata pertanian sayuran bawang. Desa tongging sudah dikenal sebagai penghasil bawang goreng dan menjadi salah satu pemasok bawang untuk sumatera utara. Hasil olahan bawang juga sudah mulai dikembangkan oleh masyarakat lokal untuk dijadikan makanan ringan (snack) dan menjadi oleh-oleh khas tongging.

Zona komersial juga menjadi salah satu yang penting sebagai tempat usaha masyarakat. Warung ikan adalah satu yang perlu menjadi perhatian. Warung ikan yang berada di sepanjang tepi danau yang merupakan area sempadan perlu untuk ditata kembali pada zona tertentu yang tidak memanfaatkan area sempada danau. Area komersial lain seperti rumah toko untuk memenuhi kebutuhan para wisatawan pada area pintu masuk kawasan tongging. Berdasarkan potensi yang dimiliki, perlu untuk menyediakan ruang yang dapat menampung aktivitas wisata outdor seperti zona camping ground dan water sport. Secara umum konsep perencanaan dan perancangan guna lahan desa tongging sebagai desa wisata yang diharapkan mampu meningkatkan nilai kawasan diperlihatkan pada gambar 5.

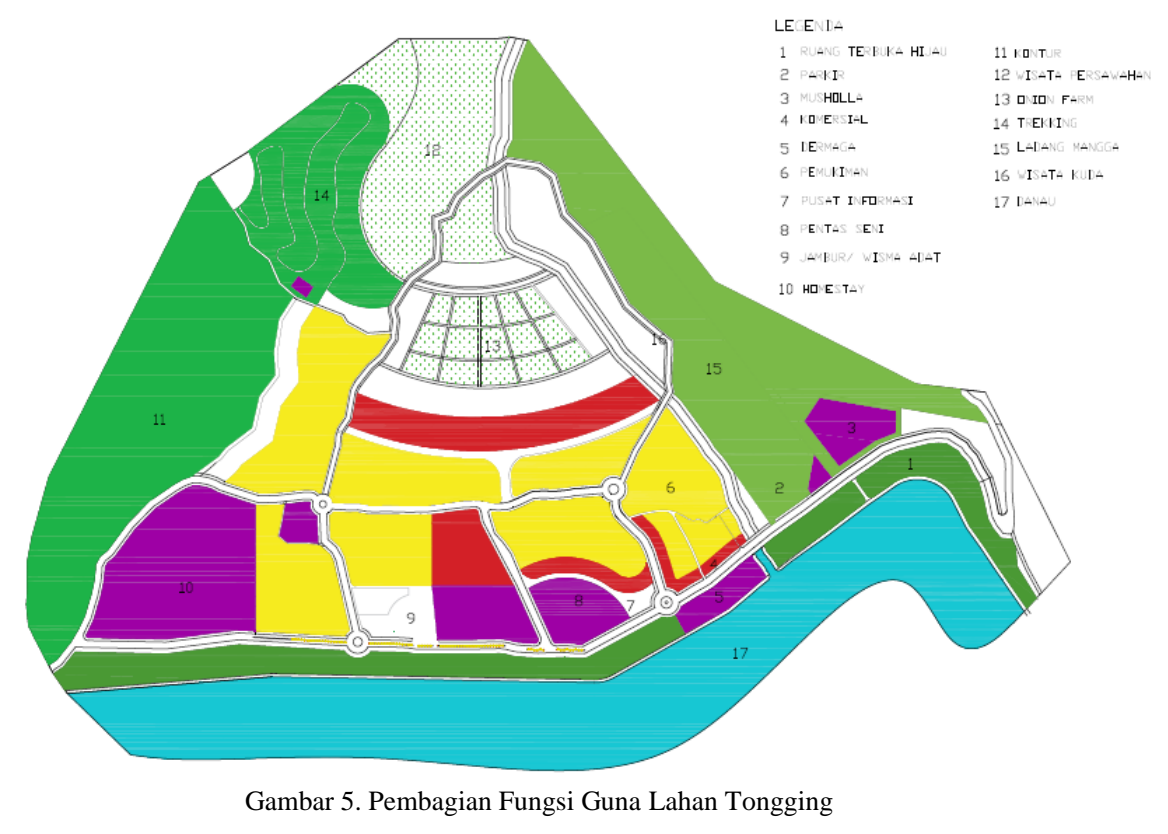

\subsection{Peningkatan Nilai kawasan}

Potensi kawasan desa tongging seperti kegiatan pertanian, perkebunan, dan ternak ikan dapat ditingkatkan dengan menambahkan fungsi komersial sebagai kawasan yang difungsikan untuk memasarkan hasil olahan pertanian. Kawasan pertanian juga dapat difungsikan sebagai kawasan wisata edukasi sehingga dapat menambah nilai ekonomi bagi masyarakat setempat. Memanfaatkan kawasan permukiman sebagai hunian komersial sebagai homstay juga dapat menigkatkan nilai kawasan sehingga dapat menambah nilai manfaat ekonomi bagi masyarakat. Konsep penataan ini diharapkan dapat meningkatkan nilai kawasan sehingga memiliki nilai ekonomi bagi masyarakat desa tongging. Disamping nilai ekonomi juga pelestarian kawasan danau dan budaya masyarakat yang menjadi amanat RTR KSN danau toba dapat lebih dimaksimalkan. 


\section{Kesimpulan}

Kawasan desa tongging yang ada saat ini belum mengakomodasi adanya perencanaan tata guna lahan yang menjadikannya sebagai wisata yang berkelanjutan. Penggunaan lahan yang ada terbagi secara organik berdasarkan aktivitas masyarakat setempat tanpa ada skenario konsep pentaan yang baik sehingga beberapa aktivitas justru dapat mengurangi nilai kawasan. Tata guna lahan dengan konsep wisata berkelanjutan yang diajukan menjadikan kawasan desa tongging lebih tanggap terhadap kebutuhan wisatawan. Kawasan sempadan danau dijadikan sebagai zona hijau membatasi aktivitas pembangunan masyarakat dengan kawasan danau untuk menjaga view terhadap danau.

Pembagian fungsi kawasan berdasarkan potensi yang ada menjadi upaya meningkatkan nilai kawasan sehingga lahan-lahan yang ada sebagai bagian dari aktivitas masyarakat dapat berkontribusi meningkatkan tingkat kesejahteraan masyarakat tongging. Sebagai konsep desa wisata yang berkelanjutan diperlukan peran serta masyarakat lokal sebagai pemeran utama, namun peran serta ini perlu mendapat dukungan dari pemerintah. Konsep peran serta pemerintah dan masyarakat dalam upaya mengaplikasikan desa wisata berkelanjutan dapat menjadi kajian lanjutan untuk menyempurnakan konsep perencanaan tata guna lahan sebagai pengembangan desa wisata yang berkelanjutan.

\section{Referensi}

[1] Ginting, N., \& Veronica, S. (2019). Tata Guna Lahan Bukit Lawang sebagai Kawasan Wisata Berkelanjutan. In Talenta Conference Series: Energy and Engineering (EE) (Vol. 2, No. 1).

[2] https://pariwisata.karokab.go.id/id/tujuan-wisata/objek-wisata-alam/10-tongging

[3] Peraturan Presiden Nomor 81 Tahun 2014 Tentang Rencana Tata Ruang Kawasan Danau Toba dan Sekitarnya.

[4] Joshi, P. (2012). A Stakeholder Networking for Sustainable Rural Tourism Development in Konkan Region of Maharashtra State (India). Reseach Paper, 1.

[5] Lane, B. (2009), Rural Tourism: An Overview, in The SAGE Handbook of Tourism Studies, (Ed. Tazim Jamal and Mike Robinson), SAGE Publications, pp. 354370 .

[6] Antara, Made, Satriawan I Ketut, A. I. N. S. (2016). Panduan Tata Kelola Desa Wisata Kendran, Pelawi Sari

[7] Hermawan, H. (2016). Dampak pengembangan Desa Wisata Nglanggeran terhadap ekonomi masyarakat lokal. Jurnal Pariwisata, 3(2), 105-117 